\title{
The influence of external oxygen concentration on axial root growth force of maize radicles
}

\author{
Nicole SOUTY \& Witold STEPNIEWSKI* \\ with the technical assistance of Colette RODE \\ I.N.R.A., Station de Science du Sol, Centre de Recherches d'Avignon, B.P. 91, F-84140 Montfavet \\ * Institute of Agrophysics, Lublin, Poland.
}

Root growth force, pressure and rate were measured for young (2-4 days) maize seedlings using a strain gauge technique at oxygen concentrations ranging from 0 to $20 \%$. The oxygen concentration was varied around the whole seedling or around its root tip. Both root growth force and pressure as well as the growth rate of the constrained roots decreased when $\mathrm{O}_{2}$ concentration was below 3-5\%. The plant response was more pronounced when the entire seedling was in the gas mixture with low $\mathrm{O}_{2}$ concentration than when the radicle only was subjected to oxygen stress. The maximum growth force of the radicles was $0.6 \mathrm{~N}$ before their deformation : this corresponded to the growth pressure $0.4 \mathrm{MPa}-0.65 \mathrm{MPa}$.

Additional key words : Seedlings, impedance, rate, pressure, aeration.

Mots clés additionnels : Plantules, résistance, vitesse, pression.

\section{INTRODUCTION}

The factors regarded as responsible for the weak growth of roots in some compacted soils are mechanical impedance and restricted oxygen supply to the root. In a recent paper (SOUTY, 1987), we described a technique developed for studying the effect of mechanical impedance on root growth. In another paper, we described measurements of the variation of growth force and rate as a function of the "inflexibility factor" $K$ of a steel plate placed under the apex. The effect of oxygen on root growth pressure was studied by EAvis et al. (1969) for peas and cotton. In this study, average root growth pressure values between 1.1 and 1.4 MPa did not change significantly if the atmosphere oxygen content at the radicle tip of peas was 3.8 and $21 \%$. In the same conditions, for cotton radicles, the authors observed a decreased pressure from $0.95-1.1 \mathrm{MPa}$ at $8 \%$ and $21 \% \mathrm{O}_{2}$ to $0.5 \mathrm{MPa}$ at $3 \% \mathrm{O}_{2}$.

It was found that oxygen uptake by main seminal roots of maize decreased at oxygen contents below $10 \%$ (SAGLIO et al., 1983, 1984) whereas the growth rate of unimpeded main seminal roots of maize began to be limited at higher oxygen concentrations, i.e. below $21 \%$ (GILL \& MilleR, 1956 ; SAGLIO et al., 1984).

In the present paper, we describe experimentation in which the mechanical impedance is constant and only the oxygen concentration is varied. The experiments were conducted with maize seedlings during development pre-emergence. We have maintained a given concentration of oxygen around the root or around the entire seedling. The first situation can occur in a com- 
pacted soil where the extent and configuration of the pore space is modified and the second situation can occur if the compacted seed bed is covered by soil crusts impeding emergence.

\section{METHODS}

The method for determining the root growth force involves the measurement of the electrical impedance of a strain gauge attached to a steel plate subjected to deformation by the growing root. The change of the impedance is directly related to deformation. The mechanical characteristics of the plates used were similar in all the measurement cells and the deflection resistance of the plate, characterized by the coefficient $\mathrm{K}$ (SOUTY, 1987) was about $750 \mathrm{~N} / \mathrm{m}$.

A diagram of the single measurement cell is given in figure 1. The method for determining growth force used in the present paper is a modification of that described by SOUTY (1987). Two principal modifications were made :

1) the measuring sensor, i.e. the steel plate with the strain gauge, was placed inside a plexiglass cell in order to maintain a given oxygen concentration ;

2) after the attachment of the cover (2) on the cell (1), the position of the sensor support (3) was

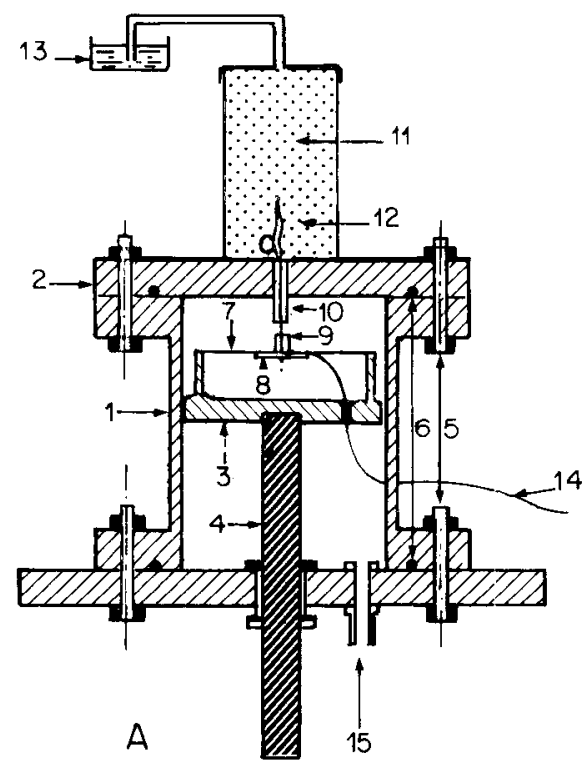

adjusted using the rod (4) so that about $2 \mathrm{~mm}$ of the root tip was in the bottom capillary (9) (internal diameter $\simeq 1.5 \mathrm{~mm}$ ).

The gas mixture of a given oxygen content entered the cell at the bottom (15), then passed through the capillary (10) near the root to the container with the sand (11) and finally to the gas flow control (13). Thus, the total seedling i.e. its radicle and its coleoptile with the seed, was in the same gas mixture.

The root growth force measurements were performed in two different ways. In the first case, the gas outlet was controlled as described above, i.e. the concentrations of oxygen around the entire seedling was the same. In the second case, the gas outlet was in the upper part of the measurement cell ; thus, only the root tip was in the gas mixture applied while the coleoptile was in the atmosphere containing about $20 \%$ oxygen. In this case however, the composition of the gas within the sand was not controlled. We emphasize that the entire coleoptile was always covered or embedded in sand and the measurements concerned the pre-emergence development stage.

A diagram of the complete measurement cell is presented in figure 2. Compressed air was mixed with nitrogen in appropriate proportions using 2 flowmeters to obtain oxygen contents of $1,2,3$, or $5 \%$. For the measurements with 0 and $20 \% \mathrm{O}_{2}$ pure nitrogen and

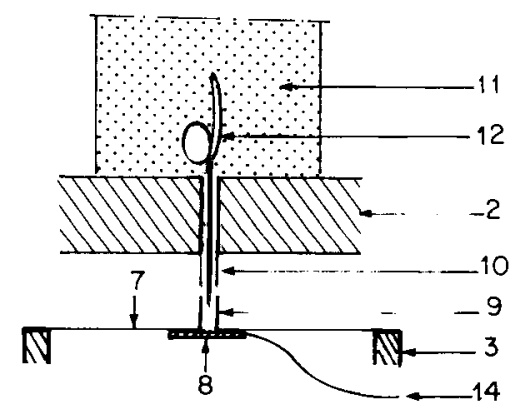

$\mathrm{B}$

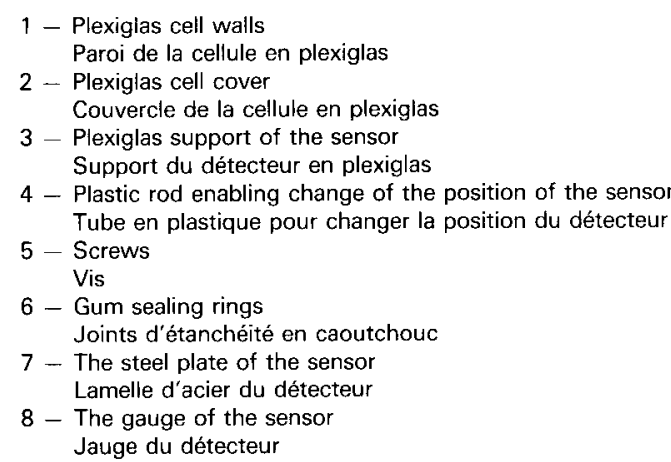

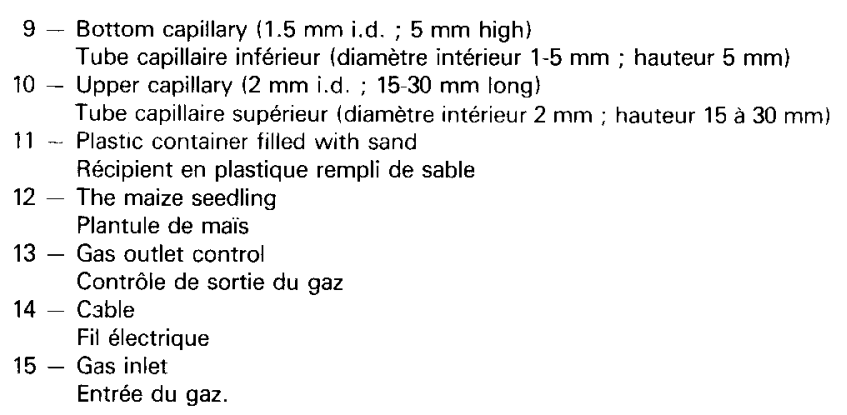




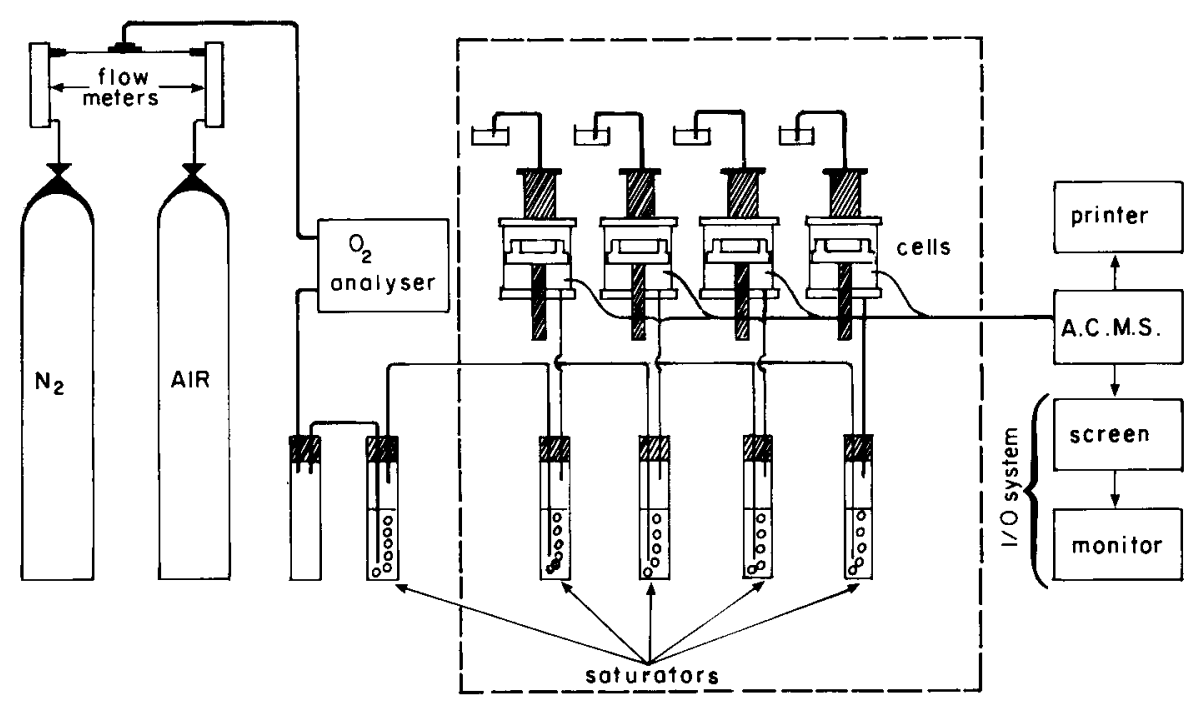

Figure 2

Diagram of the measurement system : A.C.M.S.-acquisition, control, and management system.

Schéma du système de mesures.

pure air were used. The composition of the gas mixture was controlled continuously with a paramagnetic oxygen analyser OA 272 (Taylor Servomex). The composition of the mixture was maintained constant with an accuracy of $\pm 0.2 \%$. The gas was then passed through moisture saturators to prevent the roots from drying out. The first saturator after the analyser was empty in order to protect the analyser from water entry. The measurement cells were kept in the constant temperature chamber at a temperature $21^{\circ}+0.5^{\circ} \mathrm{C}$. The gas flow was about $20 \mathrm{~cm}^{3} / \mathrm{min}$ in each cell. It was found in a preliminary test that imposed gas flow rates between 0 to $50 \mathrm{~cm}^{3} / \mathrm{min}$ did not affect the root growth force.

The signals from the strain gauges were measured and collected by an acquisition, control, and management system (UTD 64B Centralp Automatismes) connected to a video screen and to a printer. Usually the measurements were taken every ten minutes. The output signal was the relative deformation of the gauge $\varepsilon=\frac{\Delta 1}{\mathrm{a}}$ in $\mu / \mathrm{m}$.

During each measurement, the root tips acquired the diameter of the bottom capillary $(1.5 \mathrm{~mm})$. Moreover the rates of elongation of constrained roots were calculated using the output signals which were converted into deflection values of the steel plate (SOUTY, 1987).

For each measurement 30 standardized seeds (each weighing $200-240 \mathrm{mg}$ ) of maize (Zea mays L., var. I.N.R.A. Star 304) were germinated on Petri dishes for 2-4 days at a temperature of $34{ }^{\circ} \mathrm{C}$. Then, four seedlings with radicles ranging from 15 to $30 \mathrm{~mm}$ and with coleoptiles ranging from 2 to $20 \mathrm{~mm}$, were selected and installed in separate measurement cells, where watersaturated gas mixture would pass through. When the growing roots started to press the plates (usually after 1 to $3 \mathrm{~h}$ of increasing force), the air flowing through was replaced by the gas mixture of the chosen oxygen concentration. Finally, the rate of change of the root forces were measured until the forces stabilised. The experiment was replicated eight times.

\section{RESULTS}

\section{A. Root growth force}

The change of the output signal $\varepsilon$ after replacing the atmospheric air by gas mixture containing $1 \% \mathrm{O}_{2}$ is shown in figure 3 . When the entire seedling was subjected to this oxygen regime, the signal (and thus the force) decreased. But after some adaptation period it increased and then stabilized. In both curves, the ini-
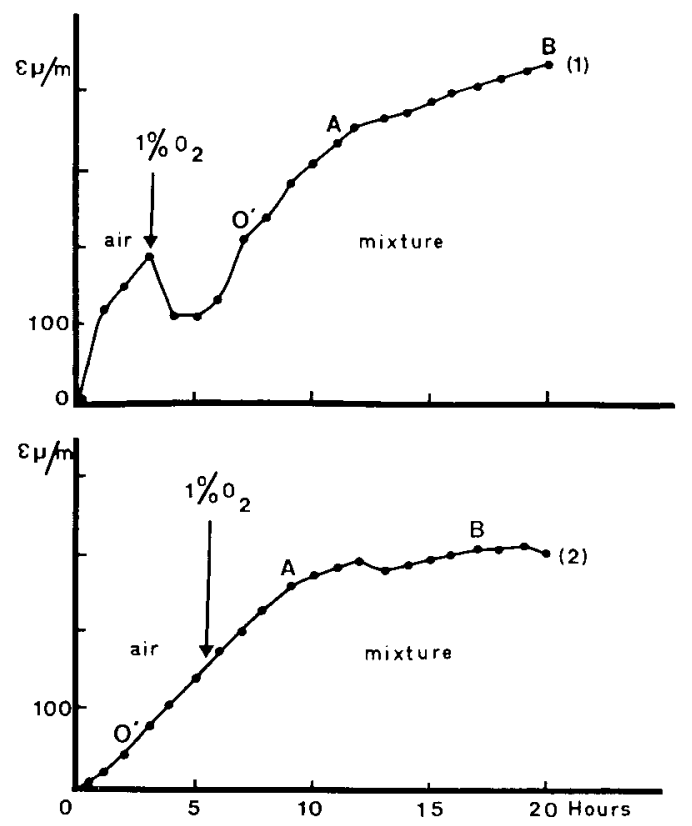

Figure 3

Change of the output signal during replacement of atmospheric air with $1 \% \mathrm{O}_{2}$ mixture for both versions of measurement: (I) whole plant in the mixture and (2) the root tip in the mixture.

Influence du remplacement de l'air par un mélange à I p. 100 en $\mathrm{O}_{2}$. 
tial growth force and hence the rate of growth showed linear relationships with time in the period represented by O'A. Subsequently, the relationship was curvilinear (AB) when root deformation was the same as that in stagnant air (SoUTY, 1987). With other oxygen mixtures, we obtained different results. At $0 \%$ oxygen, the force (from output signal $\varepsilon$ ) decreased to zero within 2$3 \mathrm{~h}$, with root death occuring later. At $2 \%$ oxygen treatment, only a small depression of the force was observed while at $5 \% \mathrm{O}_{2}$ treatment, the force continued to increase but at a smaller rate. When the root tip only was subjected to reduced oxygen concentration, the effect on root force was less pronounced and even at $0 \% \mathrm{O}_{2}$, the force did not drop to zero.

The force exerted by the root at the end of the linear range marked $\mathrm{A}$ is considered to be a maximum force of the undeformed root $\mathrm{F}_{\mathrm{MI}}$, as explained by SOUTY (1987). The force at point $B$ (fig. 3) is the maximum for the deformed root $F_{M D}$. The root growth force $F_{M L}$ is exerted by a root in order to penetrate a compacted soil vertically, but it is not always its maximum force.

The values of $F_{M L}$ as a function of oxygen concentration are presented in figure 4 ; the mean value of $\mathrm{F}_{\mathrm{MI}}$. is about $0.6 \mathrm{~N}$ at $20 \% \mathrm{O}_{2}$. If the radicle is subjected to reduced oxygen concentration, the force decreased apparently below $2 \% \mathrm{O}_{2}$ reaching about $20 \%$ of the maximum at $0 \% \mathrm{O}_{2}$.

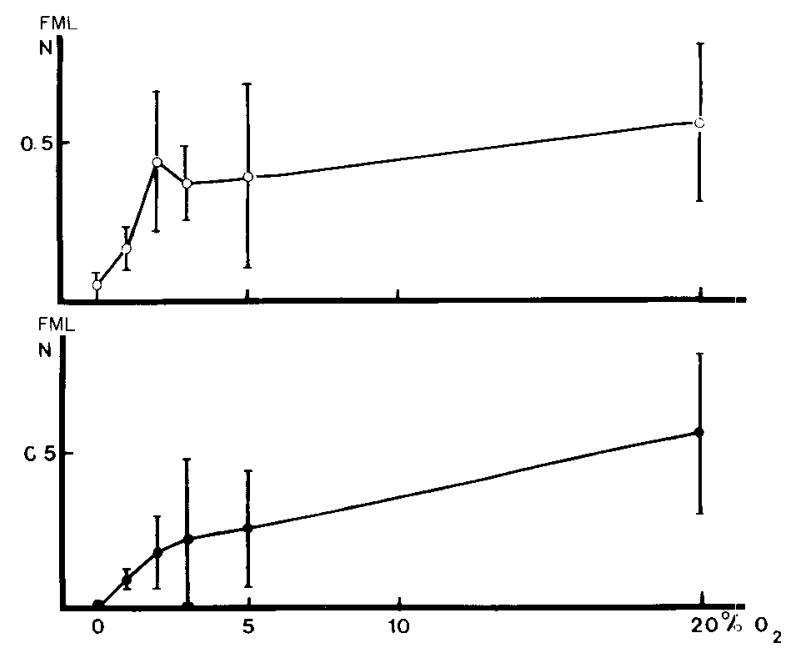

Figure 4

Maximum root growth force before rooi deformation $F_{M L}$ as a function of oxygen concentration, for both versions of the measurement :

- whole seedling in gas mixture

o root in gas mixture

(with standard deviation of the mean at $5 \%$ level of significance).

Variations de la force axiale de la racine $F_{M L}$ en fonction de la teneur en $\mathrm{O}_{2}$ du mélange, dans les deux cas:

- toute la plantule dans le mélange gazeux

- seulement la racine dans le mélange gazeux

(avec écart à la moyenne pour une probabilité de 0,05).

When the entire seedlings were treated with an atmosphere of low oxygen concentration, the effect on $F_{M L}$ was more pronounced than in the first situation.

These results for position of seedlings in oxygen atmospheres were analysed statistically.

When the entire seedling was grown in the gas mixture, the root strengths were, for every $\mathrm{O}_{2}$ concentra- tion, significantly smaller than those measured in the other situation (seminal root in mixture) (level of significance 0.05 ) ; moreover, the values in conditions of oxygen stress were smaller than these found at $20 \%$ oxygen.

When the seminal roots only were in the gas mixture, the obtained force for 2, 3 and $5 \% \mathrm{O}_{2}$ were not significantly different from the force at $20 \% \mathrm{O}_{2}$. But in both situations (entire seedling in gas mixture and seminal root in gas mixture), the measured mean force at $1 \% \mathrm{O}_{2}$ was smaller than the force measured at $2 \%$ $\mathrm{O}_{2}$ (level of significance about 0.2 ).

The corresponding growth pressures were calculated on the basis of the root diameter before experimentation. These pressures range from $0.4 \mathrm{MPa}$ at $20 \% \mathrm{O}_{2}$ to $0.13 \mathrm{MPa}$ or $0 \mathrm{MPa}$ at $0 \% \mathrm{O}_{2}$ in both experimental cases (fig. 5).

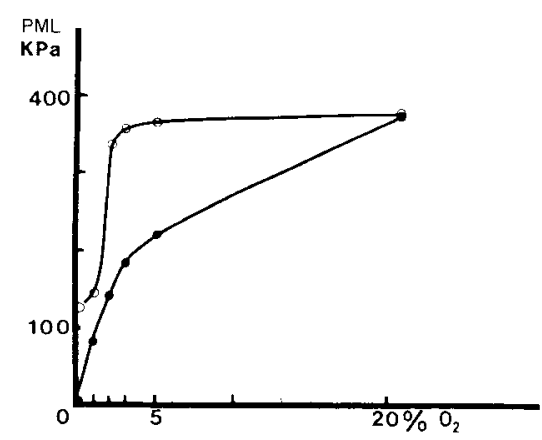

Figure 5

Growth pressure before deformation $P_{M L}$ for both versions of the measurement : (in KPa).

- whole seedling in gas mixture

o root in gas mixture.

Pression de croissance axiale de la racine : (en KPa).

- toute la plantule dans le mélange gazeux

- seulement la racine dans le mélange gazeux.

\section{B. Root growth rate}

The growth rates of constrained roots were calculated from the force exerted on the steel plate and from its mechanical characteristics (SoUTY, 1987). These values are presented for both methods of measurement in figure 6 . Their general pattern resembled that for

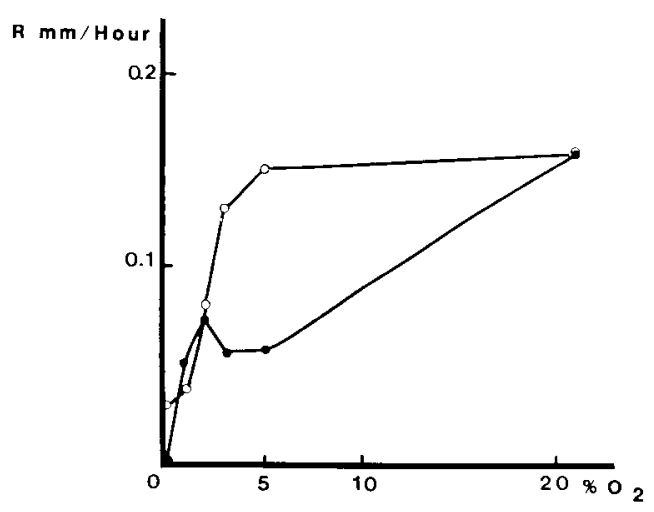

Figure 6

Growth rates of constrained maize roots (for linear range) as a function of oxygen concentration for both versions of the measurements.

Variation de la vitesse de croissance racinaire en fonction de la teneur en oxygène du mélange gazeux. 
the root growth force (fig. 5) and indicates that a decrease in root growth rate took place below $3 \%$ oxygen concentration. For the entire seedlings subjected to oxygen stress, the rate dropped to zero at $0 \% \mathrm{O}_{2}$ and when only the root tips were in the stress conditions the root growth rate at $0 \% \mathrm{O}_{2}$ was about $20 \%$ of the maximum.

The levels of significance were of the same order as those for the growth strength.

\section{DISCUSSION}

The values of the growth force determined in these experiments at $20 \% \mathrm{O}_{2}$ were of similar magnitude to those obtained by other authors who placed roots between 2 blocks of plaster (GILL \& MiLler, 1955 ; EAVIS et al., 1969). The root was unable to escape between the blocks of plaster, whereas in the first experiments in our laboratory (SOUTY, 1987), the different root anchorage allowed the root to escape.

When the whole plant was in the gaseous mixture, EAVIS found that the root growth pressure was about the same at 3.8 and at $21 \% \mathrm{O}_{2}$ for peas but, for cotton, decreased below $3 \% \mathrm{O}_{2}$. In their experiment, they did not discover whether the measured pressure was that before or after deformation of the root. In our experiments, without oxygen, the force of the root decreased to about zero. At 1 and $2 \%$ oxygen, we have observed a delay of the growth whose duration was about 2-4 hours (fig. 3). After introducing the gas mixture, the force decreased to a threshold value and then increased again reaching the same value as before the stress.

In the experiment in which root tip only was in the gas mixture, all the force values were higher than when the whole plant was exposed and we also observed delay in growth. In these experiments, we can assume an oxygen concentration gradient between seed in sand and root. Thus even if the root was in a zero-oxygen atmosphere, its force was not zero. The oxygen can reach the roots from the shoot and leaves. Moreover, the metabolism of the plant is not disturbed in the same way as when the whole seedling is subject to an oxygen stress. In this latter case, the assimilated transport to the radicle is modified.

Another author has shown that it is sometimes difficult to establish anoxic conditions for plants. Without $\mathrm{O}_{2}$ in the soil, $\mathrm{O}_{2}$ can reach the roots from the aerial organs but seeds and seedlings in stagnant water die (PERIGAud, 1966-1967 ; Trought \& Drew, 1982 ; JACKSON, 1983).

Several mechanisms can be responsible for the reduced capacity of the maize seedling roots to exert pressure at oxygen concentrations below $3 \%$. Among these are a change in the osmotic pressure, a change in the mechanical properties of the cell walls and an inhibition of cell division (EAvis et al., 1969).

The root growth rates which were determined by GILL \& MILLER (1956), showed that reduction in oxygen concentration reduced the growth rate of confined and unconfined roots. The entire seedling was in the gas mixture and the growth did not cease at concentrations of $1 \% \mathrm{O}_{2}$ in the absence of mechanical impedance (fig. 7). Furthermore, the rate of root growth

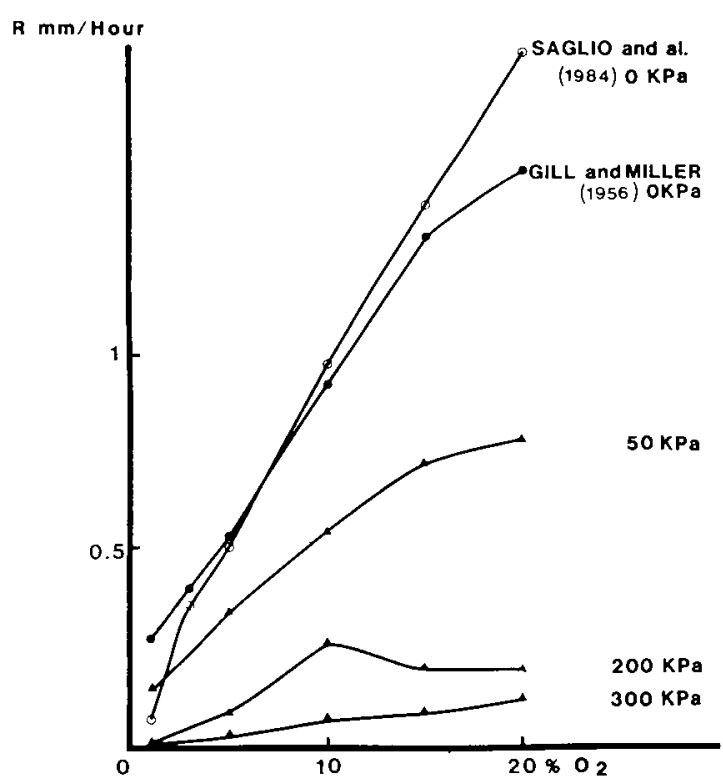

Figure 7

Growth rates of unconstrained and constrained maize roots taken from the literature.

Variation de la vitesse de croissance : données obtenues par d'autres auteurs.

was zero at a small level of impedance if the oxygen content was low. Our results show likewise. Indeed, at $1 \% \mathrm{O}_{2}$, the rates are about $6.10^{-2} \mathrm{~mm} / \mathrm{h}$ and $5.10^{-3} \mathrm{~mm} / \mathrm{h}$ for roots growing on a moderately hard and on a very hard steel plate respectively.

The work of SAGLIO et al. (1984) (fig. 7) on seminal maize root at various $\mathrm{pO}_{2}$ in a liquid medium while the seed was maintained at $21 \% \mathrm{O}_{2}$ (i.e. the same conditions of our second version) showed that the partial pressure of $\mathrm{O}_{2}$ which started to limit the growth, was significantly higher than the critical oxygen pressure for respiration. SAGLIO et al. considered that the rate of cell division did not decrease but that there was probably a non-respiratory oxidative process with a low affinity for $\mathrm{O}_{2}$ which was implied in the root elongation. The root growth rates obtained were of the same order as those determined by GILL \& MILLER, 1956.

\section{CONCLUSION}

Our data are in good agreement with those of other authors who examined root growth force in relation to oxygen concentration. Root growth force decreased markedly if oxygen concentration in the root atmosphere only was lower than $3 \%$, but in pure nitrogen the root continued to exert a force. This is attributed to a transfer of oxygen through the seedling to the root if we assume there is no oxygen transfer in the sand.

Root force decreased with reduction of oxygen concentration of the entire atmosphere of the seedling. In nitrogen only, the root could not exert a force and growth stopped. 
The results demonstrated that the oxygen concentration is a limiting factor for root growth even if internal transfer (which we assume to occur) can compensate for the $\mathrm{O}_{2}$ deficiency of the external medium.

A mathematical model of root penetration in a wet and compact soil, must take into account oxygen diffusion. Moreover, such a model would need to take into account any $\mathrm{CO}_{2}$ gradient in the seedling.

This investigation of the influence of oxygen in addition to the influence of mechanical impedance on root growth is a preliminary undertaking to further studies of root-soil interactions.

Reçu le 29 juillet 1986. Accepté le 15 février 1988

\section{ACKNOWLEDGEMENTS}

The authors thank Mrs C. RODE for technical assistance. One of the authors (W.S.) acknowledges the support of the CNRS.

\section{REFERENCES}

Eavis B. W., Ratliff L. F., Taylor H. M., 1969. Use of dead load technique to determine axial root growth pressure. Agron. J., 61, $640-643$

Gill W. R., Miller R. D., 1956. A method for study of the influence of mechanical impedance and aeration on the growth of seedling roots. Soil Sci. Soc. Proc., 20 (2), 154-157.

Jackson N. B., 1983. Approaches to relieving aeration stress in water-logged plants. Pestic. Sci., 14, 25-32.

Perigaud S., 1966. Effet de la résistance mécanique et du déficit en oxygène sur la croissance du maïs. C. R. Acad. Agric., 695-707

Perigaud S., 1967. Effet du manque d'oxygène et de l'excès d'eau au niveau des racines sur la croissance et la nutrition globale de la plante. Ann. agron., 18, 485-506.

Saglio P. H., Raymond Ph., Pradet A., 1983. Oxygen transport and root respiration of maize scedlings. Plant Physiol., 72, 1035-1039.

Saglio P. H., Rancillac M., Bruzan F., Pradet A., 1984. Initial oxygen pressure for growth and respiration of excised and intact roots. Plant Physiol., 76, 151-154.

Souty N., 1987. Aspect mécanique de la croissance des racines. I. Mesure de la force de pénétration. Agronomie, 7 (8), 623-630.

Trought M. C. T., Drew M. C., 1982. Effects of water logging on young wheat plants (Triticum aestivum L.) and on soil solutes at different soil temperatures. Plant Soil, 69, 311-326. 